\title{
THE CLASSICAL ASSOCIATION OF SOUTH AFRICA: JANUARY 1971 - JANUARY 1975
}

\author{
W J Henderson (University of Johannesburg)
}

In this article the history of the Classical Association of South Africa is continued. ${ }^{1}$

\section{Ninth CASA conference, 26-30 January 1971, Cape Town}

\subsection{Conference proceedings}

The 25 delegates were welcomed to the Opening Meeting on 26 January 1971 by the Chairperson, Prof. De Kock. Apologies for absence and good wishes for a successful conference were received from Proff. Petrie, Van Rensburg, Gonin, Farrer and Coetzee. ${ }^{2}$ Former Chief Justice L C Steyn, Patron of the Association, addressed a message to the gathering. The following in particular were congratulated: Prof. Gonin on receiving a medal of honour from the Suid-Afrikaanse Akademie for his translation of the Dutch jurist Van der Keesel; Prof. Paap and Ms Baumbach on the publication of their books, Xenophon Papyri and Studies in Mycenaean Inscriptions and Dialect respectively; and Prof. Hugo on the publication of the book Calvin's Commentary on Seneca's De Clementia in collaboration with Prof. F L Battles of Pittsburgh. ${ }^{3}$ A special word of welcome was addressed to Prof. D S Raven as visiting professor at the University of the Witwatersrand.

Under matters arising from the previous minutes it was reported that the new letterhead had now been printed, that the decision at the previous conference to compile the programme a year in advance had proved to be impracticable, ${ }^{4}$ that the matter of local editions of texts for schools and universities would be urgently pursued, ${ }^{5}$ and that the decision to devote two days of a conference to one chosen theme had not worked out as not enough papers had been offered, and that it would be preferable to assign only one day for a particular theme.

The Chairperson reported on the membership of the Association as follows: 119 Full Members, 106 Associate Members, 16 Student Members and 4 Life Members, Total 245. The Regional Branches were still active and international contacts were being upheld and promoted: Prof. Van Rooy had represented the Association at the Assemblée Générale of FIEC at Bonn in 1969, and various classicists had visited South Africa during the previous two years: Dr R Ogilvie, Prof.

1 For the earlier accounts, see Henderson 2004, 2005 and 2006.

2 Of special interest is a letter of apology for being unable to attend from Adv. George Bizos, then Chairperson of the South African Hellenic Educational and Technical Institute (SAHETI) and renowned for his defence of Nelson Mandela at the Rivonia Trial (1963-64); Bizos to S, 29 January 1971.

$3 \quad$ Reviewed in AClass 15 (1972) 168-71.

$4 \quad$ See Henderson 2006:144.

5 See Henderson 2006:145. 
A Dihle and Prof. K M T Atkinson, ${ }^{6}$ and plans were afoot to invite Prof. H LloydJones. ${ }^{7}$

Conference arrangements included the finalisation of the chairpersons and introductory speakers for each paper in accordance with a decision at the previous conference. $^{8}$

In his financial report the Treasurer, Mr Simpson, declared a balance of R3 609 , but bemoaned the fact that only $15 \%$ of Latin teachers in the Transvaal ${ }^{9}$ and $1 \%$ of students reading Classics were members of the Association. ${ }^{10}$

Prof. Van Rooy's report on the FIEC conference in Bonn had appeared earlier in Akroterion ${ }^{11}$ and was now accepted with thanks. The following decisions were made: to comply with the request of the Fédération for affiliated associations to appoint a permanent representative to liaise with FIEC, the Executive's appointment of Prof. De Kock in this capacity was ratified; the affiliation fees were to be paid by the in-coming Executive for two years in advance; and a sub-committee, consisting of Prof. Smuts (convener), Prof. Van Rooy and Messrs Simpson and Els, was appointed to provide a basis for future delegates and make recommendations at the Closing Meeting.

The financial report on Acta Classica by Prof. Naudé presented such a serious situation that discussion was postponed to the Closing Meeting and the Executive was given full authority to co-opt Proff. Naudé and Smuts, Dr Conradie and Mr Els to scrutinise the report and, if necessary, table substantial motions at the Closing Meeting.

Notice was given of a motion to nominate Prof. Viljoen and Mr Whiteley as Honorary Presidents. Before the meeting adjourned, members were requested to invite an overseas scholar to the next conference, and the Secretary was asked to convey the Association's good wishes to Proff. Petrie and Haarhoff, who was seriously ill, and to the 93-year-old Prof. John Boxwell, who had taught Latin at the University of Pretoria as lecturer (1918-19), senior lecturer (1920-23) and professor (1924-38) and was now living in County Dublin, Ireland. ${ }^{12}$

The Closing Meeting was held on 29 January 1971. The Chairperson welcomed the 21 delegates present. First the financial report on Acta Classica was discussed. It was decided that in future a free half-page advertisement would be offered to universities which subsidised articles by their academics, and gratitude would be expressed to the University of South Africa for its annual grant of R200. The recommendations of the Executive and additional co-opted members were presented and approved: 1 . that the central treasury of CASA would pay off all debts up to the end of Volume XIII; that Acta Classica would receive R500 per annum from the central treasury until the next conference; that application should be made to the Human Sciences Research Council to raise its grant from R600 to R1000 per

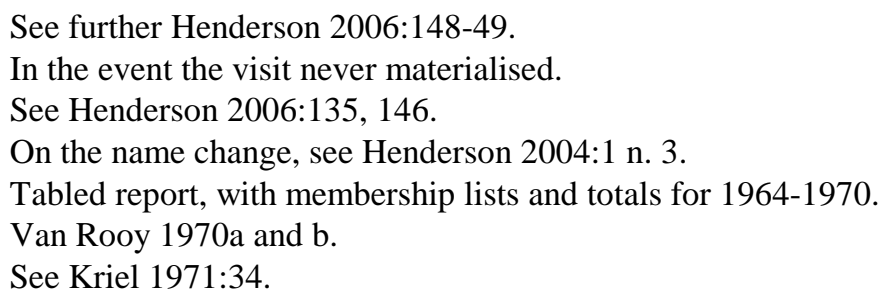


annum; that both short and long reviews be published in Acta Classica; and that the Editorial Committee obtain quotations from other printers and publishers to compare with the present one.

The following consitutional changes arising from the financial report were passed: subscriptions were raised to R120 for Life Members, R6 for Full Members, R2 for Associate Members, and R1 for Student Members; grants to regional branches were to be calculated at 50c per member, with a minimum grant of R15; regional branches were to submit annual reports of activities and finances to both the Secretary and Treasurer; grants to regional branches would only be made for a specific year and not retrospectively; reports had to be submitted before 31 July of the following year; for the purposes of payment the territorial division of members would remain and grants be made to the branch nearest the town where the member lived; and the previous Article 11 on the system of pooling costs of conferences was rescinded. The meeting approved R200 for the purchase of an addressograph apparatus and filingcabinet for the administration of the membership list.

The recommendations of the sub-committe on the FIEC representation were approved: the Association accepted the principle of the desirability of sending a representative to the General Assembly and subsequent congress, if any; the sending of such a representative would depend on the Association's finances; the Executive would therefore give early notice of FIEC meetings and request anyone who is likely to be near the venue to approach the Executive; the Executive was empowered to finalise representation; and if no member was available, the Executive could approach a suitable overseas colleague to represent CASA.

After the presentation of the reports from the Transvaal, Orange Free State, Western Cape and Eastern Cape (Grahamstown) Regional Branches, possible themes for the next conference were suggested: Social Structures and General Historical Perspectives of the Classical World; Greek and Roman Rhetoric; The Greek and Roman Historians: Historical and Literary Studies; Literary Criticism or Aspects of Literary Criticism in Antiquity; A Study of a Particular Author (with special reference to one work or section of a work); Aspects of Bronze Age History and Culture in Greece and Crete. The new Executive would make a final decision based on the offered papers. The conference fees would still be calculated on a pro-rata basis (the 'pool system') according to Article 11, and the Treasurer would finalise the account.

Invitations for the next conference in January 1973 were received from the Universities of the Witwatersrand and Pretoria; the Executive would make a final choice. The new Executive was then elected: Prof. Naudé (C), Prof. Coetzee (VC), Mr W J Henderson (S), Mr P W Jones (T), Prof. De Kock (AM). Prof. Viljoen and Mr Whiteley were elected as Honorary Presidents of the Association.

It was proposed that the possibility of a Classical tour, organised by Swan's Hellenic Cruises, and of a Latin Olympiad for school children be explored. Departments of Education should also be requested to subsidise the expenses of teachers attending Latin conferences arranged by CASA.

Motions of thanks were addressed to the Principal, Sir Richard Luyt, and the University of Cape Town for its hospitality, and to the matron and staff of Baxter Hall for accommodating delegates so comfortably; to the members of the Department of 
Classics for the arrangements; to the out-going Executive for their hard work; to the Editorial Boards of Acta Classica and Akroterion for their valuable work; and to Proff. Haarhoff and Petrie for their continuing interest in Classics and the Association. ${ }^{13}$

During the conference thirteen papers were delivered, of which three were devoted to the theme of structural analysis, followed by a session of discussion and summary.

\subsection{Administration 1971-1973}

\subsubsection{General}

The usual post-conference secretarial tasks were performed by the out-going Secretary: transfer of membership lists, finalisation of minutes, report on press coverage, ${ }^{14}$ a letter of thanks to Old Mutual for the conference folders and stationery, ${ }^{15}$ letters of appreciation, greetings and good wishes to Proff. Petrie and Haarhoff, ${ }^{16}$ letters of congratulation to Prof. Viljoen and Mr Whiteley, ${ }^{17}$ letters of thanks to the Assistant Principal and Registrar of the University of Cape Town and the Matron of Baxter Hall for their arrangements and hospitality ${ }^{18}$ and a letter of thanks to the Council of the University of South Africa for the annual grant to Acta Classica. ${ }^{19}$ The new Secretary wrote a letter of greetings and good wishes to Prof. Boxwell. ${ }^{20}$ The new Treasurer finalised the accounts on the basis of the pool system for the last time ${ }^{21}$ and settled the debt on the Acta Classica account. ${ }^{22}$

Notice was received from Mlle Ernst regarding the next Assemblée Générale of FIEC to be held in Paris on 25-26 August 1972. ${ }^{23}$ A request for the name of the Association's representative was answered by the Secretary: Prof. Richards, then in Holland, would be the CASA delegate. ${ }^{24}$

The Association was saddened by the death of one of its revered Honorary Presidents, Prof. Theodore Haarhoff, on 30 August 1971. A letter of condolence was written to his widow on behalf of CASA by the Secretary, who expressed the sense of

Minutes of Opening and Closing Meetings, 26 and 29 January 1971.

S to Baumbach, 10 February 1971; S to T, 10 February 1971; Baumbach to S, 13 February 1971

S to Old Mutual, 15 February 1971.

S to Petrie and Haarhoff, 16 February 1971; reply from Petrie, 26 February 1971.

S to Viljoen and Whiteley, 16 February 1971; replies from Whiteley, 21 February 1971 and Viljoen, 22 February 1971.

18 S to Assistant Principal, Registrar and Matron, 16 February 1971.

S to Council, 16 February 1971.

S to Boxwell, 13 April 1971. Prof. Boxwell sent a hand-written note of thanks, 27 April 1971.

Van Rooy to T, 1 March 1971; Benade to T, 4 March 1971; De Kock to T, 10 March 1971; Theron to T, 11 March 1971; Baumbach to T, 25 March 1971.

22 Naudé to T, 8 March 1971. It was decided to pay Balkema R500 immediately for Vol. XII (1969), to keep all additional income for Vol. XIII (1970), and to request a statement of the balance from Balkema for submission to the central treasury for payment.

23 Ernst to S, 25 January 1972, 29 December 1972.

24 Ernst to S, 8 May 1972; S to Ernst, 22 May 1972; accepted, Richards to S, 28 May 1972. 
loss felt by teachers and lovers of Classics here and abroad. ${ }^{25}$ On 26 October 1971 Prof. Petrie turned 90, and special tributes to him were published in Acta Classica. ${ }^{26}$

A meeting of the Executive Committee was held on 23 November 1971 at the Rand Afrikaans University ${ }^{27}$ to discuss and make decisions on all the matters raised at the recent conference. The Secretary was requested to ask Prof. Dietrich to report on progress concerning the project to publish local texts and commentaries for schools and universities. ${ }^{28}$ At the next meeting, on 25 March 1972, it was decided that the matter of a country-wide Latin Olympiad, proposed at the conference by Dr Kriel, was at that stage not feasible. ${ }^{29}$ The meeting decided to leave the matter of the Swan's Hellenic cruise of the Mediterranean in the hands of Ms Baumbach, but on her advice the project was shelved as these tours took place in the northern spring and summer when southern hemisphere universities were in full swing. ${ }^{30}$

A request was received from Dr Landels, on behalf of the Classical Association of Britain, to submit a report on the activities of CASA for the period 1970-1972 for publication in Proceedings. ${ }^{31}$

\subsubsection{Acta Classica and Akroterion}

The settlement account for Acta Classica (R2383.53) was presented for payment to the Treasurer and the payment duly made. Summaries of the contents of exchange periodicals, compiled by Mr D B Lombard in 1970-71, continued to be published in volumes of Acta Classica. In 1972 the number of periodicals received in exchange for Acta Classica had reached $45 .^{32}$

As a result of additional expenses with the publication of the series of radio talks in Volume XVI.1 \& 2 (1971) the editor of Akroterion requested the Executive Committee for urgent payment of the 1971 grant and subscription contribution and also the early payment of the R50 annual grant for $1972 .{ }^{33}$ Volume XVI.4 was dedicated to Prof. Van Rensburg on his 60th birthday: it included an appreciation, a list of his publications and an Afrikaans translation of the first 45 lines of the Oedipus Coloneus.

\subsubsection{Next conference}

The Executive Committee accepted the invitation to hold the next conference at the University of the Witwatersrand, and the venue was confirmed by the University. ${ }^{34}$ Conference arrangements were soon initiated: papers were invited, accommodation

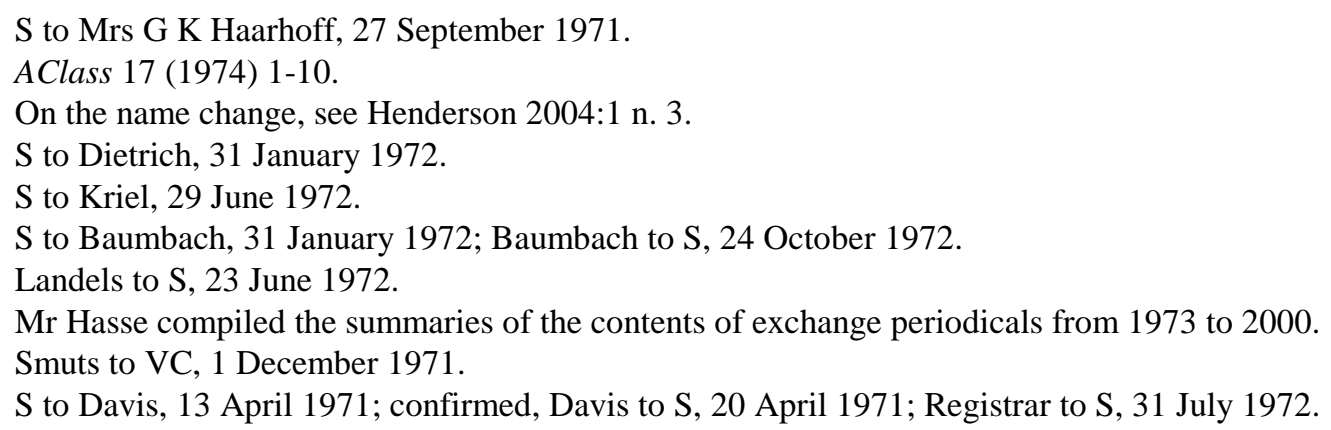


organised, ${ }^{35}$ personal invitations sent to guests of honour ${ }^{36}$ and notices sent to various newspapers. ${ }^{37}$

\subsection{The Regional Branches}

Final reports from the regional branches for the 1970 (and also 1969) activities were only submitted in 1971; the following account therefore includes activities which were not recorded in the previous article. ${ }^{38}$

\subsubsection{The Transvaal Region}

At the AGM of the Transvaal Regional Branch on 20 September 1969, Dr Benade gave a talk on Preliminary Latin as a preparation for Latin I. ${ }^{39}$ During 1970, the committee consisted of Mr De Villiers (C), Ms Möller (ST), Messrs Hasse, Simpson, J Coetzee, De Lisle and Mrs Shillington (AM). Three meetings were held. The first, in Pretoria on 14 March, was dedicated to Caesar. Pupils performed two plays: "The rider at the gate" and Shakespeare, Julius Caesar, Act 3, Scene 1. Mr Engelbrecht demonstrated the use of visual aids, and $\mathrm{Mr}$ De Lisle spoke on "The rapid reading of Latin, with comprehension". The second meeting took place in Johannesburg on 13 June. Twenty-two pupils took part in the Latin Reading Competition, after which there was a play ("Ab urbe condita"), a lecture on Roman baths by Prof. A Burger (Faculty of Architecture, Pretoria University) and a film on Homer's Odyssey. The final meeting, the AGM, was held on 3 October, on which occasion Prof. Van Rooy gave a lecture on the development of Greek sculpture. ${ }^{40}$

On 5 June 1971 the annual Latin Reading Competition took place, this time including set pieces for prepared reading, ${ }^{41}$ during the reading, a programme was presented on Roman theatre. ${ }^{42}$ At the AGM on 20 September 1971, Dr J Vogel gave a talk on "Radio carbon dating and early history", and after the meeting Roman wines and dishes were served.

35 Shillington to S, 24 October 1972, 27 November 1972; J F Truswell (Dean, Men's Halls of Residence), 18 January 1973.

36 S to Former Chief Justice L C Steyn (Patron), Dr G R Bozzoli (Principal of the University of the Witwatersrand), Dr H Müller (Hon. Vice-President), Mr M C Economides (Greek Ambassador), Mr A Pierantoni (Italian Ambassador), Dr A L Kotzee (Director of Education), Prof. Viljoen (Hon. President), and Adv. G Bizos, 15 January 1973. Apologies for absence were received from Kotzee (16 January 1973), Economides (18 January 1973), Bozzoli, who would, however, open the conference (19 January 1973), Müller (22 January 1973), Pierantoni (25 January 1973), Steyn (26 January 1973), who also requested, in view of his recent retirement, to be replaced as Patron of the Association.

37 S to the editors of The Star, The Rand Daily Mail, Die Transvaler and Die Vaderland, 20 January 1973.

38 Henderson 2006:153-55.

39 See Benade 1970.

40 Report of Chairperson to S, 1970.

41 As decided by the committee on 23 January 1971; S to Jones, 11 March 1971.

42 Circular, 24 February 1971. 
At a meeting on 18 March 1972, Dr Henderson spoke on "What Ovid tells us about the Roman calendar", which was repeated at a meeting on 29 August 1972. ${ }^{43}$

\subsubsection{The Western Cape Region}

The first meeting of 1970, on 20 March, was aimed at the needs of senior pupils, in particular the cultural background and everyday life required by the Senior Certificate syllabus. Before an audience of 200 pupils and teachers, Prof. Smuts spoke on "Roman city life: an illustrated lecture" (which concentrated on Ostia) and Miss Yeld on "Roman houses" (also illustrated with slides). ${ }^{44}$ The meeting on 6 June 1970 was for teachers. Mr Powis and Mr F Pogieter introduced the discussion on "Grammar or translation? - the alternative question in the new Senior Certificate syllabus" and "How is the new syllabus working?" Sister O'Sullivan and Prof. Hugo spoke on "Poetry and metre", concentrating on the prescribed sections of Vergil and Ovid. At the next meeting, on 22 August 1970, Prof. Smuts sketched Greek influence on Roman civilisation in a talk entitled "Graecia capta ferum victorem cepit", and Dr Conradie illustrated the continuing Greek influence in his talk on "Brecht and Sophocles." At the AGM on 18 September the following office-bearers were elected: Mr Powis (C), Ms Yeld (ST), Misses B Keeson and D Steyn (Student Representatives), Dr Conradie, Prof. Hugo, Mr H Marais, Str O'Sullivan, Mr Potgieter and Prof. Smuts (AM). ${ }^{45}$ Tributes were paid to the late Prof. Haarhoff. ${ }^{46}$

\subsubsection{Orange Free State Region}

During 1970 three 3 meetings were held, one devoted to the school syllabus (e.g. the pronunciation and reading of Vergil, the playing of Latin songs), one to discussions with the examiner for Latin, and the third to a lecture on Roman art by Ds Venter. ${ }^{47}$

\subsubsection{The Eastern Cape Region}

During 1970, the office-bearers were Prof. Dietrich (C), Mr Hewitt (VC), Dr De Wet (ST), Mrs Dietrich, Mrs and Miss Jenkins, Prof. Cattaneo and Mr Chalmers (AM). Three meetings were held: on 28 May 1970 Prof. J L Cattaneo gave a lecture on "The comedy of Aristophanes and the laughter of Rabelais"; on 30 July 1970 a programme was arranged for schools: Mr Hewitt spoke on "Plays and players in Ancient Rome" and Mr Chalmers on "The Augustan Age and our own: the political parallel." The annual presidential address was delivered in October by Prof. Dietrich on "Roman Trier." In addition, in August a play-reading of Aristophanes' The poet and the women (Thesmophoriazousai) took place. ${ }^{48}$

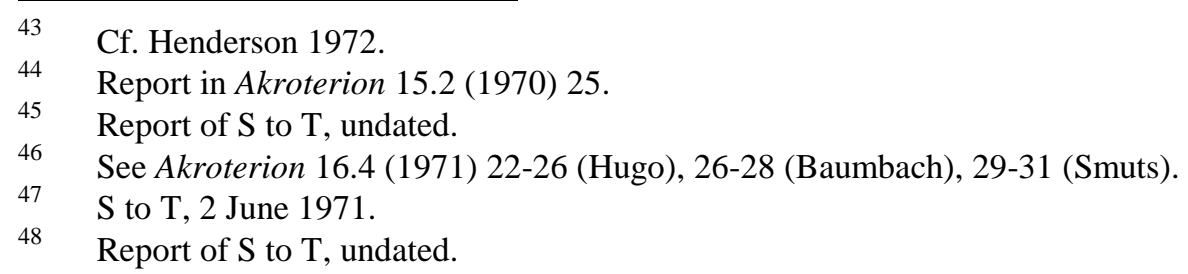


In the course of 1970 the Port Elizabeth Branch, having failed to attract sufficient interest in the area to warrant the continuation of a separate branch, was disbanded. ${ }^{49}$

\subsubsection{The Natal Region}

Lack of interest and various unforeseen circumstances also thwarted the efforts of this branch to hold regular meetings, and led to the resignation of the Secretary-Treasurer, Dr M Wakerley.

\section{Tenth CASA Conference, 22-26 January 1973, University of the Witwatersrand}

\subsection{Conference proceedings}

The Chairperson, Prof. Naudé, welcomed the 21 delegates present, in particular Dr Bozzoli and Dr R Bauman now at the University of Sydney. As usual, Prof. Petrie apologised for his absence, but sent greetings and best wishes to all members. The delegates observed a minute of silence in memory of Proff. T J Haarhoff and P V Pistorius. ${ }^{50}$ Dr Bozzoli welcomed the delegates as part of the celebrations of the Jubilee of the University in 1972, and paid tribute to J H Hofmeyr and T J Haarhoff who had contributed so much to the development of the University. Classical scholars were praised for their important research work, especially as reflected in Acta Classica, and regret expressed for at the unfortunate decline of interest in Classical studies. Congratulations were extended to Prof. Maurach on the publication of his book Der Bau von Senecas Epistulae Morales. ${ }^{51}$

The Chairperson's report noted that membership stood at 250, the Regional Branches had, with the exception of Port Elizabeth and Natal, remained active, Prof. Richards had represented the Association at the FIEC conference in Paris during August 1972, and Dr Saddington had represented the Association at the International Congress for Greek and Roman Epigraphy in Munich during September 1972.

Conference arrangements were finalised, delegates reminded to pay their own conference costs and chairpersons and introductory speakers announced. The excursion would be a visit to the Sterkfontein excavations with Prof. Philip Tobias as guide.

The Treasurer's financial report showed a balance in the savings account of R935, which with the long-term paid-up shares (R1000), interest (R283) and a steel filing-cabinet (R36) brought the assets to R2254. ${ }^{52}$ The Treasurer also gave notice of several motions for the Closing Meeting.

\footnotetext{
$49 \quad$ Lewis to S, 23 March 1972.

50 Mr A Milne, who taught at Rhodes University from 1957-61, also passed away (11 July 1972); see the obituary in Akroterion 17.2 \& 3 (1972) 35 (Baumbach).

51 Reviewed in AClass 15 (1972) 153-59.

52 Copy of financial statement tabled.
} 
The Association's liaison officer with FIEC, Prof. De Kock, reported that the next conference would take place in Madrid on 2nd-7th September 1974, and that the subscription had been raised to $\$ 30$.

The report of the Editorial Board of Acta Classica was tabled. The aim of publishing each volume in its current year was still upheld, but difficult to achieve: Vol. XIV (1972) would appear in February 1973. Reviews of publications by authors other than those in Southern Africa were now included, and selected summaries of articles in exchange periodicals appeared annually. The financial position had been eleviated: the fixed sources of income were now the Human Sciences Research Council (R1000), the CASA grant (R500) and Unisa grant (R200), totalling R1700. Fluctuating contributions from universities (R150-200), advertisements (R50-100) and income from sales (R300-400) provided another R500-700. However, the account for Vol. XIV (1971) was unexpectedly large (R2860.70) due to articles which required unusual lay-out and to the devalued Rand. R2400 for 200 pages was planned for Volumes XV (1972) and XVI (1973). ${ }^{53}$ Prof. Gonin suggested that for the next two years the volumes should be limited to 170 pages. In order to encourage local contributions, Prof. Kriel suggested that colleagues should be approached to submit articles for a particular edition, or special edition in honour of a South African classicist.

The report of the editor of Akroterion (who was absent abroad) contained a detailed account of the rising costs involved in producing the journal during the period 1966-1971. ${ }^{54}$ Subscriptions from members had, however, not been adapted accordingly. When it was the cyclostyled Newsletter, the subscription was 50c; now subscriptions were 50c for Full Members, 25c for Associate Members and 121/2c for Student Members. The editor requested an interim arrangement for the early payment of the 1972 subsidy of R50 by the Treasury; and for an increased contribution by the Treasury as from 1973 to the amount of R1.00 per member per annum. ${ }^{55}$ A committee was formed (consisting of the Executive, Proff. Baumbach and Conradie) to examine the matter and report back during the Closing Meeting. A request was made that Akroterion should be dispatched sooner to new members, especially students.

After notice of several motions had been given, Mr De Villiers pointed out that pupils entering Secondary School were advised about the choice of subjects in Standard 5 (now Grade 7), and suggested that a circular be sent to both Primary and Secondary Schools regarding the advantages of Latin as a third language. Prof. Davis advocated that the same be done in the universities. ${ }^{56}$

The Closing Meeting was attended by 28 members. Prof. Richards gave a report of the General Assembly of FIEC in Paris, pointing out that CASA's

53 Copy of report tabled.

54 1966: R337.60; 1967: R166.48; 1968: R168.43; 1969: R486.60; 1970: R204.48; 1971: R291.86. The higher costs in 1966 and 1969 were due to special issues, the centenary number and Latinitas Rediviva, to the costs of which the University of Stellenbosch contributed R136.56 and R194.93 respectively. For Vol. XVI.1 \& 2 (1971), containing a series of radio talks by scholars from various universities, no contributions had been received from those universities.

55 An amount of R152.80 had been paid in advance by the Treasurer; any surplus from this was to be carried over to 1973 .

56 Minutes of Opening Meeting, 22 January 1973. 
representation there was much appreciated and should be maintained in future. The Fédération foresaw increasing financial needs and the necessity for emphasis on the value of classical studies in the modern world. The theme of the next International Conference in Madrid in 1974, "Resistance and Assimilation to Ancient Culture in the Mediterranean World", reflected this concern. ${ }^{57}$

The reports of the Regional Branches were delivered orally, and it was suggested that they be published annually in Akroterion. ${ }^{58}$ The recommendation of the sub-committee on Akroterion, that a sum of R220 per annum be paid to the journal irrespective of membership fees, was accepted. The following motions were dealt with:

1. The Executive proposed that a sub-committee be appointed to examine the Constitution with a view to bringing the English and Afrikaans versions into closer alignment with each other. The motion was passed and the Executive Committee was entrusted with the task, with powers to co-opt; the proposed changes were to be tabled at the next conference.

2. The Executive proposed that a sub-committee for publications be appointed to go into the matter of the publication of school and university texts. The motion was passed and the Executive was entrusted with the matter.

3. The Treasurer tabled several proposals:

1. that the Association dispense with outside secretarial assistance (accepted);

2. that members be requested where possible to pay their subscriptions by bank stop order on 2 March each year (accepted);

3. that Regional Branches should manage their own financial affairs and levy their own fees in accordance with their needs; or, alternatively, that a fixed amount be paid to the Regional Branches, irrespective of membership (rejected);

4. that no receipts for subscription payments be sent unless specifically requested (accepted);

5. that the subscription fees be raised to R7.00 for Full Membership, R3.50 for Associate Membership, and R1.00 for Student Membership (the Associated Membership fee was amended to R3.00, and the motion accepted).

4. Members proposals were next dealt with:

1. Prof. Kriel proposed that the Association express its grave concern regarding the weakened position of Latin in the school curricula in the new differentiated syllabi. The motion was passed and Prof. Kriel was requested to draft and despatch telegrams to the four Directors of Education.

\footnotetext{
$57 \quad$ See Richards 1973.

$58 \quad$ Written reports were now no longer tabled at conferences but sent directly to the Treasurer, and only sporadically published in Akroterion.
} 
2. Prof. Kriel also proposed that the Association send a representative deputation to discuss the matter with the Director of Education. The motion was passed and the meeting decided to draw up a memorandum for distribution to the Education Departments. The deputation was to consist of Proff. Viljoen, Coetzee, Gonin, Naudé, Davis, Hamman, Kriel and Mr De Villiers.

3. Prof. Baumbach proposed that Article 10 of the Constitution be altered to read: "The Association meets at least once every two years in the course of the July vacation." Arguments for the proposal were the hot weather in January, the early commencement of the academic year at the Rand Afrikaans University, the consequent difficulty for both delegates and host university to arrange a conference in mid-January in accordance with the present Article 10, and more teachers would be able to attend a July conference. Arguments against the proposal were raised: other associations and the Suid-Afrikaanse Akademie met in July, delegates from Unisa would not be able to attend because of the Winter School; and there was more time in the summer to prepare papers. The motion was rejected, but the Executive Committee was requested to set the most acceptable date, preferably in late January or early February.

4. Dr Lubbe proposed that the Association make representations to the Association of Law Societies for the retention of Latin for the legal profession. The motion was accepted and the Executive Committee requested (with further members to be co-opted, if necessary) to arrange a meeting with the executive of the law societies.

5. Dr Lubbe also proposed that the Association appoint a sub-committee to function as a publicity committee to inform parents in particular of the advantages of Latin as a school subject. The motion was carried and the following appointed: Dr Lubbe, Prof. Gonin, Prof. Kriel and Mr De Villiers. The sub-committee would stress the value of Latin, approach other members for suggestions, use the Regional Branches to reach the schools, and obtain advice and suggestions from school inspectors.

6. Ms Möller proposed that the education authorities be requested to allow Standard 6 (now Grade 8) pupils to take Latin provisionally, as in the past. It was decided that this matter be dealt with by the delegation.

7. Dr Atkinson proposed that a sub-committee be appointed to examine the matter of the training of Latin teachers at universities. The problem was noted but the motion was not accepted, as the matter was already receiving attention at universities.

The invitation to hold the next conference at the University of Port Elizabeth ${ }^{59}$ was withdrawn, and an invitation from the University of the Orange Free State accepted. A discussion followed on the theme for the next conference, and delegates expressed

59 Now the Nelson Mandela Metropolitan University. 
preference to one or more of the following: Classics and the Modern World, Classical Drama, The Honours Courses and the Training of Teachers, Homeric Studies, Rhetoric and Literary Criticism, and Social and Economic History. The new Executive Committee was elected: Prof. Richards (C), Prof. Baumbach (VC), Dr Henderson (S), Dr Pauw (T), Prof. Conradie (AM). Votes of thanks were addressed to the Principal and the University of the Witwatersrand, the Department of Classics of the host university, the previous Executive Committee, Prof. Tobias for the conducted tour of the Sterkfontein Caves, the editorial boards of Acta Classica and Akroterion and the Honorary Presidents, Proff. Petrie and Viljoen and Mr Whiteley. Proff. Louw and De Kock and Ms Lewis were appointed as collaborators on the board of Acta Classica and Prof. B Hendrickx was appointed as permanent liaison officer with FIEC. The new Executive Committee was asked to revise the membership list and include a covering letter from the Treasurer explaining the new procedures. It was suggested that, despite Article 4(a) (ii) of the Constitution, Acta Classica ought to be sent to members studying abroad. Members were reminded about the Conference for Neo-Latin to be held in Amsterdam in August 1973, to which the Executive Committee would try to appoint a delegate. A delegate would also be appointed to the FIEC conference in Madrid in 1974.

Fourteen papers were read during the conference.

\subsection{Administration 1973-1975}

\subsubsection{General}

The relevant material for the Second International Congress of Neo-Latin Studies (Amsterdam, 19-24 August 1973) was received in January. ${ }^{60}$ The Secretary sent a circular to all heads of departments to suggest suitable candidates, ${ }^{61}$ and a questionnaire was then sent to members of the Executive Committee for a final choice. The names of several colleagues were put forward ${ }^{62}$ and eventually Prof. Smuts represented CASA. ${ }^{63} \mathrm{He}$ also represented the Association at the Fifth Colloquium Didacticum Classicum at Gent, on 3-7 September 1973. ${ }^{64}$

Other matters arising from decisions at the conference were included in the circular: the election of a new Patron, revision of the Constitution, the publication of school and university texts and commentaries, ${ }^{65}$ the date of future conferences and

\footnotetext{
60 Notice, programme, map and some Neo-Latin poems; Lubbe to S, 14 February 1973.

61 Circular, 27 February 1973.

62 Smuts to S, 8 March 1973; Conradie to S, 18 June 1973; S to conference organising committee, 19 July 1973.

63 P Tuynman to S, 26 July 1973.

64 For the report, see Smuts 1974.

65 Correspondence on this matter continued: Dietrich to C, 10 February 1972: the proposed publication of an edition of Juvenal; C to S, 14 May 1973: the first publication, K O Matier's Horace, Selected Odes. A Commentary (Grahamstown 1971).
} 
contact with the Association of Law Societies. The Secretary conveyed the conference's expressions of gratitude and appreciation to various persons. ${ }^{66}$

The invitation to attend the FIEC conference in Madrid on 2-7 September 1974 arrived, together with a statement indicating that CASA, on 31 December 1972, had a credit balance of 176.99 Belgian francs (then about $\$ 4$ or R3.16) on its subscription account. ${ }^{67}$ Prof. Van Rooy advised the Executive Committee that he would be in the vicinity of Madrid at the time and was willing to represent the Association. ${ }^{68} \mathrm{He}$ was, however, subsequently forced to withdraw his offer. ${ }^{69} \mathrm{Mr} \mathrm{W} \mathrm{P}$ Basson, then studying at the University of Utrecht, was delegated. ${ }^{70}$

An invitation was received from the secretary of the Classical Association of Britain to submit a report of the Association's activities for publication in Proceedings 1973. The reports for 1970 and 1971, which had arrived too late for inclusion in the previous issue, would be included with that of 1973. A report of the UK association was attached. ${ }^{71}$ Another invitation for the 1974 report duly arrived, ${ }^{72}$ but in reply the Secretary explained that there would be more substance to report after the forthcoming conference. ${ }^{73}$

\subsubsection{The position of Classics}

In the Free State, two meetings were held with the local law society, although the Secretary-General was in Pretoria. The cost of travel restricted the number of meetings and of persons involved and it was suggested that departments hold discussions with the Law Faculties of their universities. ${ }^{74}$

\subsubsection{Visitors}

The Chairperson had directed an invitation to Prof. C J de Vogel for her to visit South Africa in $1975,{ }^{75}$ but the plan suffered a setback when the Genootskap NederlandSuid-Afrika could not invite her because of a new ruling requiring visiting scholars to be under 55 years of age. ${ }^{76}$ The Chairperson persisted with the scheme. ${ }^{77}$ Arrangements were initiated for Prof. G Hermansen (Alberta, Canada), then visiting the University of Rhodesia, ${ }^{78}$ to include South Africa in his itinerary. Each university interested in receiving Prof. Hermansen would be asked to cover the internal airfare

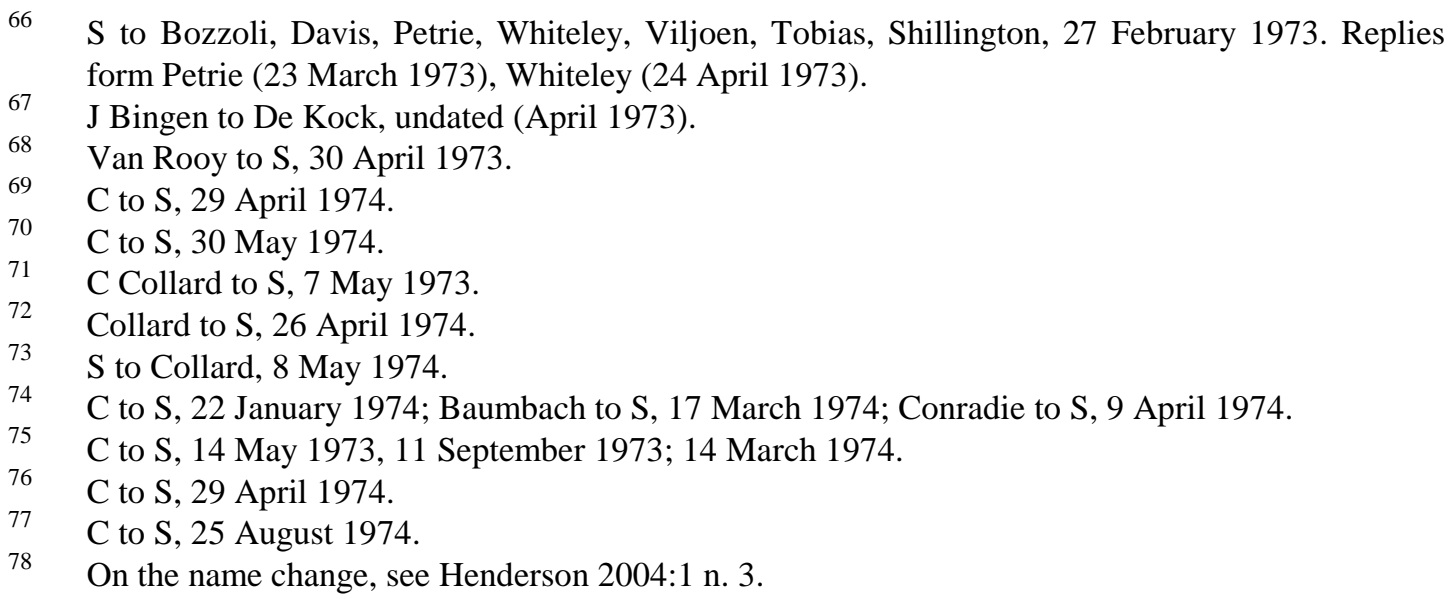


to that centre as well as the accommodation for the duration of the visit there. ${ }^{79}$ This scheme was later to prove very successful in bringing several scholars to South Africa. Prof. F R D Goodyear was visiting the University of Rhodesia as External Examiner, and the possibility of his visiting South Africa was raised. ${ }^{80}$

\subsubsection{Other matters}

The Association was approached by the Taalkommissie van die Suid-Afrikaanse Akademie vir Wetenskap en Kuns (Language Commission of the South African Academy of Science and Art) for joint discussions on the writing of Greek and Latin proper names in Afrikaans. This matter had been mooted in 1959 when a group of Classical scholars had been approached for advice. As a result of the differing views at the time, the matter had been postponed indefinitely. At their meeting in July 1974, the Akademie once again raised the issue and the Secretary, Prof. F F Odendal, had a discussion with the Secretary of CASA. Subsequently Prof. Odendal addressed a letter to the Secretary explaining the situation and (1) requesting the Association to indicate its willingness to be involved in this process; (2) if this was indeed the case, the Taalkommissie would submit its decisions so far on the matter to the Association. (3) The Association was asked to consider the possibility of holding a discussion with the Chairperson of the Taalkommissie during the CASA conference. However, as the Taalkommissie was holding its conference earlier in January 1975 than the CASA conference, and a provisional indication of co-operation was urgently required, the Secretary of CASA vouched for the Association's interest and willingness to participate and it was suggested that the Association send a few Classicists to the next conference of the Taalkommissie in Port Elizabeth in July 1975. ${ }^{81}$ A copy of the Akademie letter was sent to the Executive Committee for their comments and approval. ${ }^{82}$ The proposals of the Taalkommissie were agreed to in principle, and, in view of the travel costs involved, it was suggested that a sub-committee be appointed at the opening meeting of the conference to continue discussions with the Taalkommissie. ${ }^{83}$

\subsubsection{Next conference}

Approval to host the next conference was given by the Rector of the University of the Orange Free State for the end of January 1975 and planning was begun: final dates, matters referred from the previous conference, publicity and the excursion. ${ }^{84} \mathrm{~A}$ circular was sent out inviting members to attend and read a paper. ${ }^{85}$ Later, invitations

\footnotetext{
C to S, 11 September 1973; S to C, 17 September 1973.

Naudé to Saddington (copy to S), 16 October 1974.

Odendal to S, 23 September 1974.

S to Executive Members, 13 November 1974.

T to S, Baumbach to S; C to S, 22 November 1974; Conradie to S, 26 November 1974.

C to S, 22 January 1974; Baumbach to S, 17 March 1974; Conradie to S, 9 April 1974; Dietrich to S, 18 May 1974; S to C, 12 September 1974; C to S, 19 September 1974; PR office to C, 2 December 1974 (concerning folder); C to S, 4 December 1974. Circular, September 1974.
}

85 
were sent out to VIPs ${ }^{86}$ and delegates were given the final arrangements concerning the accommodation. ${ }^{87}$ Papers offered were correlated with the proposed themes and the programme compiled.

\subsection{The Regional Branches}

\subsubsection{The Transvaal Branch}

This branch had another stimulating programme for the year. On 17 and 18 May 1974 a Teachers' Conference was held in Pretoria. On the first day the films "The Wanderings of Ulysses" and "Vita in Roma Antiqua" (with Latin dialogue) were shown, and on the second talks were given by Prof. Henderson on Ovid and the elegiac tradition ${ }^{88}$ and by Mrs Shillington on "The evaluation of Ovid as a storyteller". Mr De Villiers, Chief Examiner for the Transvaal Education Department, discussed the setting and marking of Latin examinations. This was followed by a workshop session during which teachers could gain experience in the marking of scripts according to a memorandum.

On 3 August the annual Latin Reading Competition was held, while films were shown to the teachers and pupils. The day was completed with the performance of two short plays by the pupils of H A Jack Primary School, "Miles Gloriosus" and "A Latin Lesson" directed by Mrs M Pincus. At the AGM on 7 September, the 2400th anniversary of the birth of Plato was commemorated: Prof. R Meyer (Department of Philosophy, Pretoria) read a paper entitled "Plato - dead or alive?" During the Business Meeting, the Chairperson outlined the unpromising future of Latin in the schools and appealed to teachers at school and university to do what they could to combat the deteriorating situation. The new committee was then elected: $\mathrm{Mr}$ De Villiers (C), Prof. Henderson (VC), Mr S Gosher (S-T), Ms D Rockas, Mr M J Mans, Mrs Shillington, Mr Simpson, Ms Möller, Mr F Barnicoat and Mrs Nell (AM). Mrs Pincus and her pupils repeated their production of the two plays. At the end of the proceedings, Roman dishes were served. ${ }^{89}$

\subsubsection{The Western Cape Branch}

An annual Latin Reading Competition was introduced in August $1974,{ }^{90}$ and Dr A V Van Stekelenburg gave a talk on the Roman gladiators. ${ }^{91}$ On 7 September 1974, 70-80 guests enjoyed a "dinner of Apicius" in the Ou Hoofgebou at Stellenbosch. ${ }^{92}$

\footnotetext{
86 S to Greek and Italian Ambassadors, Dr Müller, Prof. Viljoen, Director of Education (OFS), 9 January 1975.

87 Circular, 9 January 1975.

88 See Henderson 1974.

89 See De Villiers 1974.

90 Announcement in Akroterion 18 (1973) 34-35.

$91 \quad$ See Van Stekelenburg 1974, 1975.

92 See Bruwer 1974
} 


\subsubsection{Eastern Cape Branch}

A well-attended symposium for teachers was held on 2 August 1974. During the morning session, Mrs Dietrich gave a talk on the Cambridge Latin Course, which was followed by a general discussion of the course and other problems encountered by teachers. In the evening delegates attended a cocktail party, where Latin textbooks and books on Roman civilisation, and the tapes and slides of the Cambridge Latin Course were on display. Delegates also had a chance to view the coin and vase collections of the Department of Classics. After dinner, Dr P J Maree spoke on "How to teach Latin unseens". ${ }^{93}$

\section{BIBLIOGRAPHY}

Benade, J T 1970. Voorbereidende Latyn met die oog op Latyn I. Akroterion 15.2:29.

Bruwer, S. 1974. Cena Apiciana. Akroterion 19.3:27-29.

De Villiers, J J A 1974. The Classical Association of South Africa (Transvaal Branch): Chairman's Annual Report, 1974. Akroterion 19.4:26-27.

Henderson, W J 1972. What Ovid tells us about the Roman calendar. Akroterion 17.4:9-20.

Henderson, W J 1974. Die elegiese tradisie en wat Ovidius daarvan gemaak het. Akroterion 19.1 \& 2:26-34.

Henderson, W J 2004. The Classical Association of South Africa: April 1956-January 1961. Akroterion 49:89-109.

Henderson, W J 2005. The Classical Association of South Africa: February 1961-July 1966. Akroterion 50:109-123.

Henderson, W J 2006. The Classical Association of South Africa: July 1966-January 1971. Akroterion 51:135-156.

Kriel, D M 1971. Nuus van universiteite: Pretoria. Akroterion 16.4:33-34.

Richards, W J 1973. Verslag van die vergadering van die F I E C 1972. Akroterion 18. $3 \& 4: 15-19$.

Smuts, F 1974. Verslag van Vyfde Kongres van die "International Bureau voor de studie van de problemen van het onderwijs in het Grieks en Latijn" (Colloquium Didacticum Classicum Quintum), Gent, 3-7 September 1973. Akroterion 19.3:16-22.

Van Rooy, C A 1970a. Verslag van die Dertiende Algemene Vergadering van die Fédération Internationale des Associations d'Éudes Classiques (FIEC). Akroterion 15.1:30-35.

Van Rooy, C A 1970b. Die Vyfde Internasionale Klassieke Konferensie. Akroterion 15.2:21-24.

Van Stekelenburg, A V 1974. Die Romeinse gladiatore (1). Akroterion 19.4:14-23.

Van Stekelenburg, A V 1975. Die Romeinse gladiatore (1). Akroterion 20.2 \& 3:2837.

$93 \quad$ Report in Akroterion 19.4 (1974) 28. 